\author{
Łukasz Danel \\ Katedra Nauk Politycznych \\ Uniwersytet Ekonomiczny w Krakowie
}

\title{
Irlandzki Senat i nieudana próba jego zniesienia
}

\section{Streszczenie}

Artykuł podejmuje tematykę Senatu Republiki Irlandii oraz kampanii referendalnej, która miała miejsce w związku z projektem rządowym dotyczącym likwidacji drugiej izby irlandzkiego parlamentu. Uchodzi ona współcześnie za jedną z najbardziej osobliwych drugich izb funkcjonujących w ramach europejskich zgromadzeń bikameralnych. Wpływ na taki obraz Senatu Irlandii ma przede wszystkim absolutnie wyjątkowa metoda powoływania jego składu osobowego, prowadząca do sytuacji, w której Senat ten staje się w ramach irlandzkiego systemu politycznego nieco ubezwłasnowolnioną instytucją władzy, dodatkowo wzmacniającą większość rządową.

W artykule w sposób syntetyczny przedstawiono najważniejsze informacje dotyczące Senatu Irlandii oraz jego uprawnień, a także wskazano na okoliczności polityczne i ekonomiczne, które doprowadziły do rozpisania referendum w sprawie likwidacji tej izby parlamentu. Zaprezentowane zostały także argumenty obu stron sporu dotyczące zasadności przeprowadzenia takiej reformy ustrojowej, przebieg kampanii referendalnej, a także wyniki samego referendum.

Słowa kluczowe: bikameralizm, senat, parlament, referendum, Irlandia. 


\section{Wprowadzenie}

Na początku października 2013 r. Irlandczycy dosyć niepodziewanie opowiedzieli się w referendum przeciwko likwidacji swojego Senatu ${ }^{1}$ - jednej z najciekawszych i najbardziej oryginalnych drugich izb współczesnych parlamentów. Wynik ten był dlatego niespodziewany, że przez bardzo długi czas, w zasadzie jeszcze nawet na krótko przez samym referendum, sondaże opinii społecznej wskazywały, że inicjatywa irlandzkiego rządu spotka się z akceptacją ze strony społeczeństwa i Irlandia stanie się jednym z wielu krajów o jednoizbowym parlamencie. Okazało się jednak, że kierowany przez Endę Kenny’ego koalicyjny rząd Fine Gael i Labour Party poniósł dotkliwą porażkę, a zatem irlandzki parlament pozostanie - przynajmniej na jakiś czas - bikameralny.

Próbę likwidacji irlandzkiego Senatu można osadzić w szerszym kontekście dyskusji nad potrzebą utrzymywania drugich izb parlamentu. Patrząc na mapę polityczną świata, można wskazać wiele przykładów państw, które z różnych powodów zdecydowały się na likwidację drugich izb swych legislatyw. Często decydowały o tym względy praktyczne, gdy przykładowo uznawano te izby za nadto kosztowe, hamujące proces prawotwórczy, niedemokratyczne, obstrukcyjne, czyli po prostu zbędne. Spośród państw, które powodowane tego rodzaju motywami zlikwidowały swe drugie izby, warto wymienić chronologicznie Nową Zelandię (1950 r.), Danię (1953 r.), Szwecję (1969 r.), Ekwador (1979 r.), Islandię (1991 r.), Peru (1992 r.), Wenezuelę (1999 r.) czy Chorwację (2001 r.). Bywało jednak również tak, że drugie izby likwidowano jako relikt obalonych w drodze rewolucji, zamachów stanu czy przewrotów reżimów autorytarnych, w których izby te były jednym z elementów fasadowych konstytucji mających na celu legitymowanie takiego niedemokratycznego reżimu².

Na przestrzeni dwóch ostatnich dekad dyskusja nad zasadnością utrzymywania Senatu toczyła się także w Polsce. Problem ten być może nigdy nie urósł w naszym kraju do rangi kluczowego postulatu wyborczego, ale likwidację polskiego Senatu zapowiadał choćby przed wygranymi wyborami w 2001 r. Sojusz Lewicy Demokratycznej, ale też Platforma Obywatelska uczyniła go jednym z czterech haseł przygotowywanego przez siebie w 2005 r. referendum „4 $\times$ tak”. I choć referendum to nie doszło do skutku, można się było spodziewać, że partia polityczna, która

${ }^{1}$ Właściwa nazwa tej izby parlamentu brzmi: Seanad Éireann, jednak dla ułatwienia w tekście stosowane będzie określenie „Senat”. Podobnie jeśli chodzi o pierwszą izbę parlamentu Irlandii choć jej pełna nazwa to Dáil Éireann, stosowane będzie określenie „Izba Reprezentantów”.

${ }^{2}$ Dobrym przykładem takiego procesu jest zniesienie drugiej izby parlamentu portugalskiego po tzw. rewolucji goździków i obaleniu dyktatorskich rządów Marcela Caetano (następcy Alberta Salazara). Rewolucja ta miała miejsce w 1974 r., a konstytucja z 1976 r. wprowadziła unikameralny parlament. 
w ostatnim czasie dwukrotnie wygrała w Polsce wybory parlamentarne, będzie próbowała swe sztandarowe postulaty ustrojowe wcielić w życie. Nic bardziej mylnego. Mimo zapowiedzi żaden polski rząd nie zdecydował się na poważną debatę nad zmianami Konstytucji RP, które miałyby objąć czy to zmniejszenie liczby posłów, czy też likwidację Senatu. I choć postulat ten wciąż ze zmienną częstotliwością przewija się w polskiej debacie publicznej, trudno sobie na chwilę obecną wyobrazić jakąś poważną próbę jego realizacji.

Choć współcześnie w skali świata dominują zgromadzenia jednoizbowe, pytanie o to, czy lepsza jest jedno-, czy dwuizbowa struktura parlamentu, jest z natury rzeczy pytaniem źle postawionym. Równie daremna wydaje się prosta enumeracja zalet i wad każdego z tych rozwiązań, zwłaszcza że często można podać wiele trudnych do zakwestionowania argumentów potwierdzających tezę o korzyściach płynących z bikameralizmu, jak i tę o zbyteczności drugiej izby. W zasadzie nawet każdej zalecie można przypisać równolegle wadę. Weźmy przykładowo tezę mówiącą o tym, że dwuizbowość powoduje wydłużenie procesu legislacyjnego, a często nawet jego celową obstrukcję czy przewlekanie przez drugą izbę. Jest to oczywiście prawdą, ale z drugiej strony można powiedzieć, że równocześnie takie wydłużenie sprzyja jakości, uwiarygodnieniu oraz uszlachetnieniu prawa tworzonego przez parlament.

Niniejszy artykuł ma na celu ukazanie dyskusji nad zasadnością utrzymywania Senatu Irlandii, a zwieńczonej ogólnokrajowym referendum, w którym większość Irlandczyków opowiedziała się przeciwko likwidacji drugiej izby swojego parlamentu. W pierwszej części artykułu zostanie ukazana specyfika Senatu Irlandii, zwłaszcza pod kątem metody kreacji jego składu osobowego oraz konstytucyjnych uprawnień, czyli dwóch kwestii które stały się ważnymi (choć nie jedynymi) argumentami w dyskusji toczącej się przed referendum. Przebieg tej dyskusji zostanie przedstawiony w kolejnej części artykułu, przede wszystkim pod kątem ścierania się racji zwolenników i przeciwników propozycji rządu irlandzkiego. Artykuł kończą wnioski, które można wyprowadzić z całej tej sytuacji - i to zarówno dla samej Irlandii, jak i dla bikameralizmu jako określonej struktury współczesnych zgromadzeń parlamentarnych.

\section{Charakterystyka irlandzkiego Senatu i jego specyfiki}

Irlandzki Senat wpisany został już do Konstytucji Wolnego Państwa Irlandzkiego z 1922 r., które - jeszcze jako członek Brytyjskiej Wspólnoty Narodów uznawało zwierzchnią władzę brytyjskiego monarchy reprezentowanego przez swego gubernatora. Utworzony na mocy tej konstytucji parlament irlandzki (Oireachtas Éireann) składał się z króla oraz dwóch izb: Izby Reprezentantów oraz 
Senatu, co było rzecz jasna bezpośrednim nawiązaniem do brytyjskiej tradycji ustrojowej wyrażającej się w słynnej formule „króla w parlamencie”. Po dojściu do władzy w 1932 r. partii Fianna Fáil (Żołnierze Losu) skupiającej zwolenników zupełnego zerwania przez Irlandię więzi z Wielką Brytanią tylko kwestią czasu było urzeczywistnienie się tej idei. Co prawda, jedna $\mathrm{z}$ wielu poprawek do konstytucji z 1936 r. znosiła Senat, ale w nowej ustawie konstytucyjnej (obowiązującej zresztą do dnia dzisiejszego), która po zaakceptowaniu przez naród w referendum weszła w życie w ostatnich dniach 1937 r., parlament pozostał bikameralny. Przepisy nowej konstytucji odnoszące się do Senatu - czy to jeśli chodzi o metodę kreacji jego składu osobowego, czy też uprawnienia - bardzo nieznacznie różniły się od tych obowiązujących na mocy ustawy zasadniczej z 1922 r.

Senat Republiki Irlandii jest bez wątpienia wzorowany na brytyjskiej Izbie Lordów, z tą jednak zasadniczą różnicą, że został on wkomponowany nie w monarchiczny, lecz republikański system rządów. Wiele osobliwych rozwiązań dotyczących składu osobowego i funkcjonowania Izby Lordów da się tłumaczyć przede wszystkim siłą i pielęgnowaniem brytyjskiej tradycji ustrojowej. W przypadku irlandzkiego Senatu decydujące pod tym względem wydaje się także długoletnie pozostawanie pod wpływem dominacji państwa angielskiego, a następnie brytyjskiego. Nawet współcześnie irlandzki parlament pod wieloma względami wydaje się niemalże kalką parlamentu obradującego w murach Pałacu Westminsterskiego - czy to jeśli chodzi o procedury, czy też relacje pomiędzy dwiema izbami parlamentu.

Tym, na co przede wszystkim zwraca się uwagę w przypadku irlandzkiego Senatu, jest absolutnie nietypowa metoda wyłaniania jego składu osobowego. Artykuł 18 Konstytucji Irlandii stanowi, że Senat składa się z 60 członków, spośród których 11 jest mianowanych bezpośrednio przez premiera Irlandii (zwanego Taoiseachem), który zostaje mianowany na to stanowisko na pierwszym po wyborach posiedzeniu nowo wybranej Izby Reprezentantów3 . Pozostałych 49 senatorów powoływanych jest według dość skomplikowanej procedury wyborczej. Ich wybór musi być dokonany nie później niż 90 dni po rozwiązaniu poprzedniego parlamentu zgodnie z proporcjonalną formułą wyborczą, przy zastosowaniu metody tzw. pojedynczego głosu przechodniego (single transferable vote $-\mathrm{STV})^{4}$ oraz

${ }^{3}$ W Irlandii wybory do Izby Reprezentantów muszą odbyć się w ciągu maksymalnie 30 dni od rozwiązania poprzedniego parlamentu.

${ }^{4}$ Metoda ta jest stosowana także przy innych wyborach odbywających się w Irlandii - prezydenckich, parlamentarnych (czyli do Izby Reprezentantów), lokalnych oraz do Parlamentu Europejskiego. 
w głosowaniu tajnym. Bierne prawo wyborcze przysługuje obywatelom Irlandii, którzy ukończyli 21 lat5.

Spośród wspomnianych 49 wybieralnych senatorów sześciu to tzw. członkowie uniwersyteccy (university members), a pozostałych czterdziestu trzech - członkowie panelowi (panel members). Członków uniwersyteckich wybierają (w liczbie po trzech) absolwenci dwóch uniwersytetów: Narodowego Uniwersytetu Irlandii (National University of Ireland) oraz Uniwersytetu Dublińskiego (University of Dublin, zwanego także Trinity College). Czynne prawo wyborcze przysługuje tym absolwentom, którzy na danej uczelni uzyskali tytuł naukowy. Listy takich absolwentów są na obu uczelniach regularnie uaktualniane. Aby zostać kandydatem w takich wyborach, trzeba otrzymać nominację dwóch tzw. zarejestrowanych elektorów uniwersyteckich, a także akceptację pozostałych ośmiu elektorów. Nie trzeba natomiast być absolwentem danej uczelni ani pozostawać z nią w jakimkolwiek związku ${ }^{6}$. Konstytucja co prawda dopuszcza możliwość wprowadzenia takich zmian ustawowych, które umożliwią dokonywanie wyboru członków uniwersyteckich także przez absolwentów innych uczelni (lub instytucji szkolnictwa wyższego), ale póki co - tego rodzaju zmiany nie zostały przeprowadzone.

Jeszcze bardziej skomplikowane zasady i procedury regulują wybór 43 członków panelowych, którzy mają stanowić - jak pisze J. Szymanek [2004, s. 141] - emanację określonych grup zawodowo-społecznych, gdyż są wskazywani przez odpowiednie grona (kurie) skupiające środowiska kulturalne, naukowe, przemysłowe, rolnicze i administracyjne. Czynne prawo wyborcze w tych wyborach przysługuje członkom nowo wybranej Izby Reprezentantów, członkom ustępującego Senatu, a także członkom rad miejskich i rad hrabstw (łącznie jest to ok. tysiąca osób). Choć i tutaj konstytucja dopuszcza wprowadzenie zmian w systemie wyboru tej grupy senatorów, to jak dotąd zmiany takie nie zostały dokonane.

Zgodnie z art. 18 Konstytucji Irlandii senatorowie ci wybierani są z pięciu list kandydatów zawierających nazwiska osób, które posiadają odpowiednią wiedzę oraz doświadczenie praktyczne z zakresu dziedzin i zawodów pogrupowanych w pięciu następujących panelach:

5 Procedury i zasady głosowania oraz wszelkie przepisy związane z przeprowadzeniem wyboru tych 49 senatorów zawarte są w Konstytucji Irlandii oraz następujących ustawach: Seanad Electoral (Panel Members) Act 1947, Seanad Electoral (Panel Members) Act 1954, Seanad Electoral (University Members) Act 1937, Electoral Act 1997 oraz Electoral (Amendment) Act 1998. Teksty powyższych aktów prawnych znajdują się na stronie internetowej Parlamentu Irlandzkiego pod adresem: http://acts.oireachtas.ie (data dostępu: 10.02.2014).

${ }^{6} \mathrm{~W}$ razie śmierci, rezygnacji lub uznania za niezdolnego do pełnienia swej funkcji któregoś z członków uniwersyteckich w trakcie kadencji parlamentu, na danej uczelni przeprowadzane są zgodnie z tymi samymi zasadami - wybory uzupełniające. 
- panel edukacji i kultury: język i kultura narodowa, literatura, sztuka, edukacja oraz inne dziedziny zawodowe, które zgodnie z ustawą mogą zostać określone jako przynależne do tego panelu,

- panel rolnictwa: rolnictwo i dziedziny pokrewne oraz rybołówstwo,

- panel pracy: praca zarówno zorganizowana, jak i niezorganizowana,

- panel przemysłu i handlu: przemysł i handel, w tym bankowość, finanse, księgowość, inżynieria i budownictwo,

- panel administracji: administracja publiczna i świadczenia socjalne, w tym dobrowolna aktywność społeczna.

Nominacja kandydatów na senatorów jest także skomplikowana, gdyż w każdym panelu dokonywana jest ona w ramach dwóch podlist: podlisty organów nominujących (the Nominating Bodies subpanel) oraz podlisty parlamentu (Oireachtas subpanel). Każdy z organów nominujących ${ }^{7}$ ma prawo do nominowania kandydatów w ramach odpowiedniego panelu i tworzą oni podlistę organów nominujących. Równocześnie grupa czterech członków nowo wybranej Izby Reprezentantów lub ustępującego Senatu może także dokonać nominacji jednego kandydata w ramach każdego panelu, z tym zastrzeżeniem, że dany parlamentarzysta może być tylko w jednej takiej czteroosobowej grupie. Ci kandydaci z kolei tworzą podlistę parlamentu. A zatem listy kandydatów w ramach poszczególnych paneli składają się z dwóch podlist - sporządzonej przez organy nominujące i sporządzonej przez członków parlamentu. Konstytucja Irlandii stanowi, że z każdej z takich pięciu list może zostać wybranych minimum pięciu, a maksimum 11 senatorów. Jednakże dodatkowo podczas wyborów z każdej podlisty musi zostać wybrana minimalna liczba senatorów. Szczegółowy podział miejsc w Senacie pod kątem zarówno ich podziału pomiędzy poszczególne panele, jak i minimalnej liczby członków, którzy muszą zostać wybrani z każdej podlisty w ramach danego panelu, zawiera tabela 1.

Warto jeszcze nadmienić, że inaczej niż w przypadku członków uniwersyteckich ewentualne wybory uzupełniające (w razie śmierci lub rezygnacji danego senatora, bądź też stwierdzenia jego niezdolności do piastowania tego stanowiska)

${ }^{7}$ Rejestr organów uprawnionych do nominowania kandydatów w poszczególnych panelach jest podpisywany i przechowywany przez sekretarza senatu (Clerk of the Seanad), który jest urzędnikiem odpowiedzialnym za przeprowadzenie wyborów. Są to różnego rodzaju organizacje kwalifikowane będące organizacjami określonych zawodów, profesji czy funkcji społecznych. Aby znaleźć się w takim rejestrze, czyli stać się organem nominującym, dana organizacja musi mieścić się w ramach konkretnego panelu i być związana z jego interesami. Nie są rejestrowane organizacje nastawione na zysk, a każda organizacja może zostać zarejestrowana tylko w ramach jednego panelu. Taki rejestr jest każdego roku uaktualniany, można się z nim zapoznać na stronie internetowej parlamentu Irlandii pod adresem: http://www.oireachtas.ie/viewdoc.asp?DocID=23178\&CatID=123 (data dostępu: 4.02.2014). 
przebiegają według nieco odmiennych zasad. Czynne prawo wyborcze posiadają w nich bowiem jedynie członkowie Izby Reprezentantów oraz Senatu ${ }^{8}$.

Tabela 1. Podział tzw. panelowych członków Senatu Irlandii pomiędzy poszczególne panele wraz z określeniem minimalnej liczby kandydatów wybieranej z każdej z podlist w ramach odpowiednich paneli

\begin{tabular}{|l|c|c|}
\hline \multicolumn{1}{|c|}{ Nazwa panelu } & $\begin{array}{c}\text { Łączna liczba wybieranych } \\
\text { senatorów }\end{array}$ & $\begin{array}{c}\text { Minimalna liczba senatorów } \\
\text { wybieranych z każdej podlisty }\end{array}$ \\
\hline Edukacji i kultury & 5 & 2 \\
\hline Rolnictwa & 11 & 4 \\
\hline Pracy & 11 & 4 \\
\hline Przemysłu i handlu & 9 & 3 \\
\hline Administracji & 7 & 3 \\
\hline
\end{tabular}

Źródło: http://referendum2013.ie/the-seanad-background-information (data dostępu: 4.02.2014).

Parlament Irlandii (formalnie składający się z Prezydenta, Izby Reprezentantów oraz Senatu) jest typowym przykładem bikameralizmu asymetrycznego, w którym faktyczna władza skoncentrowana jest w pierwszej izbie. I choć w realizacji funkcji ustawodawczej obie izby uczestniczą teoretycznie na równych prawach, decydujący głos zarówno w inicjowaniu projektów ustaw, jak i w ocenie projektów rządowych należy do Izby Reprezentantów. Już sama zarysowana powyżej metoda kreacji składu osobowego Senatu prowadzi do sytuacji, w której skład ten w dużym stopniu odzwierciedla układ sił politycznych w Izbie Reprezentantów. W praktyce nie ma w Senacie czegoś takiego jak afiliacje partyjne, a jego członkowie dzielą się na dwie grupy - wspierających rząd oraz jego przeciwników [Lane 2002, s. 127].

W procesie stanowienia prawa - naczelnej funkcji realizowanej przez każdy parlament - rola Senatu jest absolutnie drugorzędna. Najlepszym na to dowodem jest fakt, że co prawda inicjatywa ustawodawcza należy do obu izb parlamentu, ale projekty ustaw finansowych (money bills) oraz projekty ustaw zmieniających konstytucję mogą być inicjowane jedynie przez Izbę Reprezentantów. Podobnie jak w parlamencie brytyjskim większość projektów rządowych (czyli traktowanych jako ważniejsze) rozpoczyna swoją ścieżkę legislacyjną w pierwszej izbie. I choć teoretycznie obie izby mogą w projektach ustaw proponować swoje

8 Jeśli wakat pojawi się w ramach podlisty parlamentu, nominować kandydata może grupa dziewięciu członków Izby Reprezentantów i Senatu. Jeśli natomiast ma to miejsce w ramach podlisty organów nominujących - nominacji takiej dokonuje każdy organ nominujący przypisany do konkretnego panelu. 
poprawki, Senat może zmienić lub odrzucić dany projekt tylko wtedy, jeśli zgodę na to wyrazi Izba Reprezentantów.

Każda ustawa przechodzi w obu izbach przez pięć takich samych etapów procesu legislacyjnego (pierwsze czytanie, drugie czytanie, etap komisyjny, etap rozpatrywania raportu komisji, końcowe głosowanie nad projektem). Gdy projekt ustawy trafia z Izby Reprezentantów do Senatu, ten ma na jego rozpatrzenie 90 dni. Jeśli Senat odrzuci projekt ustawy, wprowadzi do niego poprawki, na które nie zgadza się Izba Reprezentantów, lub nie podejmie żadnej decyzji, pierwsza izba irlandzkiego parlamentu może nie liczyć się ze zdaniem Senatu i w ciągu kolejnych 180 dni przyjąć rezolucję, w której zostanie ogłoszone uchwalenie tego projektu przez obie izby parlamentu ${ }^{9}$. Projekty ustaw finansowych z kolei nie tylko nie mogą być inicjowane w Senacie, ale jeśli trafią pod jego obrady, nie można do nich wprowadzać żadnych poprawek ${ }^{10}$. Senatorowie nie mogą opóźniać wejścia w życie tego rodzaju legislacji, mogą co najwyżej w ciągu 21 dni przekazać swoje sugestie i uwagi, które jednak mogą zostać przez Izbę Reprezentantów zlekceważone. Wszystko to stanowi ewidentne złamanie zasady równorzędności izb [Szymanek 1999, s. 116].

W ramach funkcji ustawodawczej Senat Irlandii posiada jednak pewne szczególne, wyłączne uprawnienia. Każdy projekt ustawy po zaakceptowaniu przez parlament wymaga podpisu prezydenta, co musi mieć miejsce w terminie nie krótszym niż pięć i nie dłuższym niż siedem dni od chwili przedłożenia do podpisu [Konstytucja Irlandii..., s. 22]. Zgodnie z art. 26 Konstytucji, przed jego złożeniem prezydent może - w odniesieniu do większości projektów ustaw ${ }^{11}$ - zdecydować o przekazaniu ich do Sądu Najwyższego, aby ten orzekł, czy są one (lub ich części) zgodne z konstytucją. Wspomniane uprawnienie Senatu polega na tym, że może on złożyć do prezydenta petycję o niepodpisywanie danego projektu ustawy, dopóki w tej sprawie nie wypowie się naród w referendum ogólnokrajowym. Do takiej sytuacji może dojść w przypadku projektów ustaw niosących istotne dla kraju

${ }^{9}$ Ciekawa jest też sytuacja, w której projekt ustawy został zainicjowany w Senacie, po czym trafia do Izby Reprezentantów, która wprowadza do niego poprawki. Zgodnie z konstytucją projekt taki zostaje wówczas ogłoszony jako zainicjowany w Izbie Reprezentantów.

${ }^{10}$ Decyzję, czy dany projekt ustawy podpada pod kategorię ustaw finansowych, podejmuje - analogicznie jak spiker brytyjskiej Izby Gmin - przewodniczący Izby Reprezentantów (Ceann Comhairle). Senat taką decyzję może zakwestionować poprzez wysłanie do prezydenta Irlandii prośby o skierowanie tej sprawy do Komisji ds. Przywilejów (Committee of Privileges). W takiej sytuacji prezydent może (choć nie musi) powołać Komisję ds. Przywilejów, która jest rodzajem komisji wspólnej obu izb (składa się z równej liczby przedstawicieli Izby Reprezentantów i Senatu, a na jej czele stoi sędzia Sądu Najwyższego), musi rozstrzygnąć tę kwestię w ciągu 21 dni i jej decyzja jest ostateczna.

${ }^{11} \mathrm{Z}$ wyjątkiem projektów ustaw finansowych, projektów ustaw zmieniających konstytucję oraz projektów ustaw uchwalonych w nagłych sytuacjach. 
zmiany $^{12}$. Aby petycja taka mogła być do prezydenta skierowana, wymagana jest na to zgoda większości senatorów i co najmniej 1/3 członków Izby Reprezentantów. Prezydent może na taką propozycję przystać, co oznacza, że nie podpisuje danego projektu ustawy aż do momentu jego akceptacji w referendum. Drugim wyłącznym uprawnieniem Senatu jest złożenie tzw. wniosku o wcześniejszy podpis (earlier signature motion), który może skutkować skróceniem czasu, w którym prezydent może podpisać dany projekt ustawy [Lane 2002, s. 128].

Poza funkcją ustawodawczą Senat Irlandii - jak każda druga izba parlamentu - realizuje także inne funkcje. I choć w odniesieniu do funkcji kontrolnej obie izby mają możliwość kontrolowania całokształtu polityki rządu i administracji, polityczna odpowiedzialność rządu (a zatem możliwość wyrażenia mu wotum nieufności) może być egzekwowana tylko przez Izbę Reprezentantów. Jedynym w zasadzie uprawnieniem kontrolnym Senatu jest możliwość kierowania przez senatorów zapytań do rządu i jego poszczególnych ministrów [Szymanek 2005, s. 369]. Może to mieć miejsce także w trakcie odbywających się w Senacie debat, podczas których dyskutowane są różne aspekty działalności rządu, często w obecności przedstawicieli rządu, a czasami nawet i samego premiera. W ramach realizacji funkcji kreacyjnej Senat Irlandii bierze udział w procedurach powoływania rzecznika praw obywatelskich ${ }^{13}$, odwoływania ze stanowiska sędziów Sądu Najwyższego, rewidenta księgowego, a także głównego audytora [Lane 2002, s. 128]. Ciekawym uprawnieniem Senatu realizowanym w ramach często wyodrębnianej (choć dziś już mocno historycznej) funkcji sądowniczej parlamentu jest udział drugiej izby irlandzkiego parlamentu w procedurze egzekwowania odpowiedzialności konstytucyjnej prezydenta tego kraju, będącej dość specyficzną odmianą znanego w tradycji anglosaskiej impeachmentu. Każda z izb parlamentu może mianowicie - jeśli uzna, że prezydent naruszył prawo - postawić go w stan oskarżenia, działając w charakterze swoistego prokuratora. Jeśli do tego dojdzie, druga $\mathrm{z}$ izb, działając $\mathrm{w}$ charakterze sądu, rozpatruje postawione zarzuty, prowadząc odpowiednie postępowanie i wydając $\mathrm{w}$ tej sprawie prawnie wiążącą decyzję (wyrok). To w zasadzie jedyny przejaw egalitarności obu izb irlandzkiego parlamentu, które w tym konkretnym przypadku dysponują dokładnie takimi samymi uprawnieniami. W każdym innym obszarze funkcji realizowanych przez parlament są one względem siebie - jak wcześniej wspomniano - nierównorzędne [Szymanek 2005, s. 410-411].

12 Obowiązkowo pod referendum, przed podpisaniem ich przez prezydenta, muszą być poddane projekty ustaw wprowadzające zmiany w konstytucji.

${ }^{13}$ Irlandzki ombudsman jest nominowany przez prezydenta na wniosek obu izb parlamentu, które w tej sprawie przyjmują odpowiednią rezolucję. W takiej rezolucji na stanowisko ombudsmana rekomendowana jest konkretna osoba. 
Wśród pozostałych funkcji Senatu warto jeszcze wymienić tzw. funkcję europejską, związaną z członkostwem Irlandii w Unii Europejskiej. W odniesieniu do części legislacji europejskiej, w celu jej skutecznej implementacji do irlandzkiego porządku prawnego wymagana jest bowiem wcześniejsza zgoda obu izb parlamentu. Zgoda taka musi być wyrażona choćby w przypadku takich zmian traktatowych, które zmierzają do wprowadzenia zasady głosowania kwalifikowaną większością głosów w tych obszarach, w których wcześniej obowiązywała zasada jednomyślności ${ }^{14}$. Podobnie sytuacja wygląda w odniesieniu do tzw. procedury wzmocnionej współpracy (enhanced co-operation), umożliwiającej grupie państw członkowskich UE zacieśnienie w określonym obszarze współpracy w ramach Unii. Gdyby Irlandia chciała wziąć udział w takiej formule współpracy, wymagana jest do tego zgoda zarówno Izby Reprezentantów, jak i Senatu. W wyniku porozumienia zawartego pomiędzy Unią Europejską a Irlandią i Wielką Brytanią kraje te mogą (opt in), ale nie muszą (opt out), uczestniczyć w konkretnych działaniach związanych z tzw. obszarem wolności, bezpieczeństwa i sprawiedliwości (kwestie dotyczące azylu, imigracji, kontroli granicznych, współpracy pomiędzy policją czy instytucjami sądowymi $)^{15}$. Wszelkie decyzje dotyczące dołączenia do współpracy w tych obszarach wymagają uprzedniej zgody obu izb parlamentu.

Nakreślony powyżej obraz irlandzkiego Senatu pozwala postawić tezę, że zarówno metoda kreacji jego składu osobowego, jak i przewidziane Konstytucją Irlandii uprawnienia czynią z niego izbę, której głównym zadaniem jest wspieranie większości tworzącej rząd, zwłaszcza gdy większość ta jest w Izbie Reprezentantów dosyć niepewna. Senat nie wchodzi w konflikt z Izbą Reprezentantów, ani tym bardziej z rządem, jego rola sprowadza się w najlepszym wypadku do roli neutralnego obserwatora, choć w praktyce stanowi on dość wyraźne wzmocnienie wyłonionej w wyborach do Izby Reprezentantów większości. To wszystko oczywiście pozwala na stawianie pytań o zasadność utrzymywania drugiej izby, która niewiele wnosi do prac irlandzkiego parlamentu, a w pewnym stopniu wydłuża proces decyzyjny w parlamencie i generuje określone koszty związane $\mathrm{z}$ funkcjonowaniem. Tego rodzaju pytania były stawiane już od wielu lat, natomiast wyborcze zwycięstwo Fine Gael i powstanie rządu na czele z Endą Kenny'm spowodowały, że postulat likwidacji irlandzkiego Senatu po raz pierwszy zaczął być nie tylko rozpatrywany, ale doszło do działań, które miały na celu wprowadzenie tego rozwiązania w życie.

${ }^{14} \mathrm{~W}$ przypadku poważniejszych zmian - np. prowadzących do zwiększenia uprawnień instytucji Unii Europejskiej - wymagane jest najczęściej referendum ogólnokrajowe.

15 Chociażby dlatego te dwa kraje nie są stronami porozumienia z Schengen, a z drugiej strony uczestniczą w programach dotyczących wspólnej polityki azylowej czy też współpracy pomiędzy sądami. 


\section{XXXII poprawka do Konstytucji Irlandii i fiasko referendum}

Po kryzysie finansowym, który w 2008 r. bardzo dotkliwie uderzył w Irlandię i sprawił, że stanęła ona na granicy bankructwa, całkiem uzasadnione (ale też politycznie chwytliwe) okazywały się wszelkie postulaty mające na celu ograniczenie wydatków publicznych, zwane potocznie ,zaciskaniem pasa”. Po latach rządów dominującej na irlandzkiej scenie politycznej Fianna Fáil trudna sytuacja gospodarcza połączona ze społecznymi frustracjami skłoniły premiera Briana Cowena (następcę Bertiego Aherna) do podjęcia decyzji o wycofaniu się z życia publicznego po zakończeniu kadencji parlamentu. Fianna Fáil z kretesem przegrała wybory, a władzę objęła koalicja Fine Gael i Labour Party. Obecny już od dłuższego czasu w irlandzkiej polityce nowy premier Enda Kenny nie uchodził co prawda za zagorzałego przeciwnika Senatu, lecz na fali popularności postulatów mających przynieść budżetowe oszczędności, już na dwa lata przed wyborami zapowiadał, że jeśli jego partia te wybory wygra - Senat zostanie zlikwidowany. I choć w kampanii wyborczej pojawiały się także głosy, że być może wystarczy odpowiednia reforma Senatu, wśród liczących się partii (obok Fine Gael także Labour Party oraz Sinn Féin) przeważała chęć doprowadzenia do sytuacji, w której parlament irlandzki pozostałby jednoizbowy. Umowa koalicyjna pomiędzy Fine Gael a Labour Party w części dotyczącej politycznych reform oszczędnościowych zawierała m.in. zapis o ,znaczącym ograniczeniu składu parlamentu poprzez zniesienie Senatu, jeśli zostanie to zaaprobowane przez naród w referendum, a także zmniejszenie liczby deputowanych do Izby Reprezentantów"16.

Prace nad zmianą konstytucji okazały się dużo bardziej skomplikowane, niż się to rządowi pierwotnie wydawało, co znacząco opóźniło złożenie w parlamencie odpowiednio przygotowanego projektu ustawy w tej sprawie. Wymagało to bowiem nie tylko usunięcia z konstytucji odpowiednich zapisów dotyczących Senatu, ale także takiego opracowania przepisów przejściowych, które będą umożliwiały odpowiednią pracę parlamentu, dopóki zmiana ta na dobre nie wejdzie w życie, a zatem do kolejnych wyborów do Izby Reprezentantów (przewidywanych na 2016 r.). Pierwsze czytanie projektu ustawy wprowadzającej XXXII poprawkę do Konstytucji (Thirty-second Amendment of the Constitution Bill 2013) miało miejsce w Izbie Reprezentantów 4 czerwca 2013 r. i po trzech tygodniach, po przejściu pozostałych etapów procedury legislacyjnej, 25 czerwca projekt został przyjęty przez pierwszą izbę irlandzkiego parlamentu ${ }^{17}$. Niespełna miesiąc później

${ }^{16}$ Programme for Government 2011. Tekst umowy koalicyjnej dostępny jest na stronie internetowej irlandzkiego rządu pod adresem: http://www.merrionstreet.ie/index.php/about/programme-for-government (data dostępu: 5.02.2014).

17 http://www.oireachtas.ie/viewdoc.asp?DocID=23654 (data dostępu: 5.02.2014). 
- 17 lipca - został zaakceptowany przez Senat ${ }^{18}$. Oznaczało to konieczność rozpisania referendum ogólnokrajowego, gdyż zgodnie z art. 46 Konstytucji Irlandii - wszelkie poprawki do niej muszą być zatwierdzone przez naród.

Wejście tej zmiany w życie miało oznaczać, że Senat Irlandii przestanie funkcjonować po kolejnych wyborach do Izby Reprezentantów (a dokładniej rzecz ujmując - jeden dzień przed zebraniem się nowo wybranej izby) i żadne nowe wybory do Senatu nie będą już miały miejsca. Przewidywał to nowy, przejściowy artykuł Konstytucji (19A), który miał po tym fakcie zostać usunięty z tekstu. Z Konstytucji miały oczywiście zostać wykreślone zapisy mówiące o istnieniu Senatu jako części Parlamentu Irlandii, metodzie powoływania jego składu osobowego, uprawnieniach itp.

Ważne przepisy przejściowe zostały wpisane w kolejny przejściowy artykuł Konstytucji Irlandii (50A), który również zniknąłby z tekstu Konstytucji w dniu poprzedzającym zebranie się nowo wybranej Izby Reprezentantów. Przepisy te dotyczyły mianowicie losu projektów ustaw, nad którymi w dniu likwidacji Senatu wciąż trwałyby prace. Jeśli jakiś projekt ustawy byłby wtedy na etapie rozpatrywania przez jedną z izb parlamentu, traciłby swoją ważność, choć mógłby być później od nowa wprowadzony pod obrady w Izbie Reprezentantów. Projekty ustaw oczekujące już tylko na podpis prezydenta (np. rozpatrywane przez Sąd Najwyższy pod kątem ich konstytucyjności) nie traciłyby swej ważności. Rzecz jasna, po obaleniu Senatu nowe projekty ustaw byłyby rozpatrywane i przyjmowane już tylko przez Izbę Reprezentantów, a możliwość zakwestionowania decyzji przewodniczącego Izby Reprezentantów o zakwalifikowaniu danego projektu ustawy jako finansowego przeszłaby z Senatu na Izbę Reprezentantów, która mogłaby przyjąć rezolucję obalającą taką decyzję. Analogicznie wszelkie procedury związane z implementacją legislacji europejskiej byłyby rozpatrywane - w sposób naturalny - już tylko przez jedną izbę parlamentu. Także na Izbę Reprezentantów przeszłaby możliwość złożenia do prezydenta tzw. wniosku o wcześniejszy podpis. Odpowiednie zmiany w Konstytucji Irlandii zostały także dokonane w tych artykułach, które przewidywały opisane powyżej uprawnienia kreacyjne Senatu, a także uprawnienia sądownicze związane z egzekwowaniem odpowiedzialności konstytucyjnej prezydenta Irlandii.

W trakcie kampanii przedreferendalnej zwolennicy obalenia Senatu ${ }^{19}$ podnosili - jak wspomniano powyżej - przede wszystkim argumenty o wysokich kosztach jego funkcjonowania i o zbyt dużej liczebności Parlamentu Irlandii w stosunku

18 Tamże. Pełny tekst projektu ustawy, który został zaakceptowany przez obie izby parlamentu, znajduje się na stronie internetowej Parlamentu Irlandii pod adresem: http://www.oireachtas.ie/ documents/bills28/bills/2013/6313/b63a13d.pdf (data dostępu: 5.02.2014).

19 Obok większości liczących się w Irlandii partii politycznych (Fine Gael, Labour Party, Socialist Party oraz Sinn Féin) były to również takie ponadpartyjne inicjatywy, jak np. grupa One 
do mieszkańców tego kraju. Premier Enda Kenny wielokrotnie podkreślał, że likwidacja Senatu przysienie oszczędności budżetowe w kwocie 20 milionów euro rocznie. Oskarżał też Senat, że przy niewielkich uprawnieniach, które ta izba posiada, nie wnosi ona do prac parlamentu pożądanej jakości, a senatorowie nie zrobili nic, by zakwestionować - nieodpowiedzialną zdaniem premiera - politykę jego poprzedników, która doprowadziła Irlandię na skraj bankructwa ${ }^{20}$. Rzecz jasna, w dyskusji tej przewijały się także argumenty mówiące o niedemokratycznej, nieprzystającej do współczesnych uwarunkowań europejskich metodzie kreowania składu osobowego Senatu, a także oderwaniu Senatu od kontaktu $\mathrm{z}$ opinią publiczną.

Wśród przeciwników pomysłu rządu irlandzkiego przeważały z kolei argumenty o konieczności bardziej zreformowania niż zlikwidowania istniejącego od początku państwa irlandzkiego Senatu. Linię taką przyjęła chociażby Fianna Fáil - główna partia opozycyjna ${ }^{21}$. Warto też pamiętać, że w 2013 r. zarówno w Izbie Reprezentantów, jak i w Senacie pojawiły się projekty ustaw, których celem była zmiana sposobu wyboru senatorów choćby poprzez wprowadzenie, w miejsce głosowania panelowego, wyborów powszechnych. Ważnym argumentem przeciwników całkowitej likwidacji Senatu było to, że doprowadziłoby to do znacznej koncentracji władzy w rękach jednoizbowego parlamentu, a co za tym idzie większości rządowej z premierem na czele. Byłoby to istotnym naruszenie systemu hamowania się i równoważenia władz (checks and balances) w Irlandii. Podkreślano także, że wbrew pozorom Senat (głównie dzięki wysokim kwalifikacjom swych członków) wnosi bardzo wiele do prac nad legislacją, często wprowadzając do niej ważne poprawki, które powodują, że jakość ustaw jest wyższa, niż gdyby o ich treści decydowała tylko Izba Reprezentantów. Kwestionowano też rządowe wyliczenia odnośnie do oszczędności, jakie może przynieść likwidacja Senatu, utrzymując, że nie da się tego tak precyzyjnie oszacować, a podane przez premiera koszty funkcjonowania Senatu są mocno zawyżone ${ }^{22}$.

Data referendum (a w zasadzie dwóch, gdyż Irlandczycy głosowali także nad poprawką do Konstytucji Irlandii ustanawiającą Sąd Apelacyjny) została ustalona na piątek 4 października 2013 r. Jeszcze ostatnie badania opinii społecznej, przeprowadzone pod koniec września 2013 r. i opublikowane na początku tygodnia

House - zob. http://www.breakingnews.ie/ireland/one-house-seanad-abolition-campaign-launches-605607.html html (data dostępu: 5.02.2014).

${ }^{20} \mathrm{http}: / / w w w . g a z e t a p r a w n a . p l / a r t y k u l y / 722047$, oszczedzaja-zwalniajac-poslow.html (data dostępu: 5.02.2014).

${ }^{21}$ Do głosowaniu przeciwko likwidacji Senatu namawiały również inne partie polityczne np. Green Party czy Workers' Party of Ireland.

${ }^{22}$ http://www.theguardian.com/world/2013/oct/03/irish-voters-seanad-abolition-parliament (data dostępu: 5.02.2014). 
poprzedzającego referendum, wskazywały, że przewaga zwolenników obalenia Senatu jest ogromna i wynosi $17 \%$ (44\% za likwidacją, $27 \%$ - przeciwko) ${ }^{23}$. Wyniki referendum były zatem dla rządu i opinii publicznej sporym zaskoczeniem. Przy stosunkowo niskiej frekwencji (39,17\%) 51,73\% Irlandczyków zagłosowało przeciwko likwidacji Senatu, podczas gdy 48,27\% było odmiennego zdania $^{24}$. Premierowi Kenny'emu nie pozostało nic innego, jak zapowiedzieć, że rząd będzie musiał zająć się teraz reformą drugiej izby irlandzkiego parlamentu.

\section{Wnioski}

Dyskusję nad zasadnością utrzymywania drugiej izby parlamentu, która przez ostatnie lata toczyła się w Irlandii, należy z jednej strony rozpatrywać w szerszym kontekście dyskusji nad zaletami i wadami zgromadzeń bikameralnych. Z drugiej jednak strony ważne jest także to, aby zwrócić uwagę na konkretne uwarunkowania irlandzkie, które - jak się wydaje - miały zasadnicze znaczenie dla osób, które w październiku 2013 r. zdecydowały się wziąć udział w referendum. Jeśli chodzi o pierwszą z wymienionych płaszczyzn, spór ten - jak już wspomniano we wstępie - jest w zasadzie niemożliwy do rozstrzygnięcia. Choć na świecie przeważają obecnie zgromadzenia jednoizbowe, nie można $\mathrm{z}$ tego wyprowadzić wniosku, że taka struktura parlamentu jest lepsza czy bardziej efektywna. Zresztą nie sposób też obecnie zaobserwować jakiegoś wyraźnego trendu w kierunku unikameralizmu, a przewaga ilościowa parlamentów jednoizbowych wynika przede wszystkim stąd, że takie rozwiązanie przyjęte zostało przez większość państw, które wskutek różnego rodzaju procesów politycznych pojawiły się na mapie politycznej świata w drugiej połowie XX w. Te nowe państwa, wobec braku tradycji dwuizbowości, zdecydowały się po prostu na ustanowienie parlamentów jednoizbowych.

Nie ma uniwersalnych motywacji, którymi kierują się państwa decydujące się na utrzymanie, utworzenie bądź poddanie reformie dwuizbowego parlamentu, podobnie jak nie sposób wskazać na jakikolwiek zestaw determinant polityczno-społeczno-ekonomicznych, których łączne zaistnienie miałoby prowadzić w prostej linii do bikameralizmu. Z. Kiełmiński [2004, s. 27] stawia tezę, że w poszczególnych krajach europejskich stosunek do dwuizbowości jest odzwierciedleniem motywów zarówno wynikających z narodowej specyfiki, zakorzenionych w tradycji ustrojowej czy systemie politycznym, jak i tych, które można określić mianem politycznych czy koniunkturalnych. A zatem dopóki w określonych

\footnotetext{
23 Tamże.

24 http://www.rte.ie/news/2013/1005/478516-live-referendums (data dostępu: 5.02.2014).
} 
uwarunkowaniach historycznych czy społecznych istnieją racjonalne przesłanki do utrzymywania podzielonego parlamentu po to, aby w jak najlepszym stopniu mógł on realizować przypisane mu funkcje i zadania - bikameralizm ma rację bytu. W przypadku państw federalnych argumentacja przemawiająca za dwuizbowością jest wyjątkowo trudna do obalenia i w takich państwach ta idea ustrojowa w zasadzie nie jest w ogóle podważana. Ale już państwa o prostej strukturze terytorialnej nie są z dwuizbowością nierozerwalnie związane, zatem decyzja o utworzeniu bądź utrzymywaniu drugiej izby państwa unitarnego jest wypadkową wielu argumentów i decyzji o naturze stricte politycznej.

Przypadek Irlandii, tak jak każdy inny, należy zatem rozpatrywać jako przypadek osobny. Rzecz jasna wzięcie pod uwagę ogólnych argumentów przewijających się w dyskusji nad sensem istnienia podzielonego parlamentu także wydaje się uzasadnione, niemniej konieczne jest przeprowadzenie analizy próby likwidacji irlandzkiego Senatu w ścisłym powiązaniu z irlandzkimi uwarunkowaniami ustrojowymi i politycznymi, a także wzięcie pod uwagę konkretnych argumentów zarówno zwolenników, jak i przeciwników takiego rozwiązania. Jednak nawet takie podejście badawcze nie pozwala na sformułowanie jednoznacznej diagnozy, dlaczego inicjatywa irlandzkiego rządu się nie powiodła, a już tym bardziej odpowiedzi na pytanie, czy Irlandczycy podjęli w swym referendum właściwą decyzję. Na tę decyzję wpływ miało zapewne wiele różnych, mniej bądź bardziej politycznych czynników. Okazało się, że tradycja ustrojowa oraz chęć utrzymania pewnej równowagi pomiędzy różnymi instytucjami władzy w ramach irlandzkiego systemu politycznego wzięły górę nad ocierającymi się często o polityczny populizm argumentami o konieczności dokonywania określonych cięć w wydatkach publicznych. Irlandia nie jest zresztą pierwszym krajem, w którym tego rodzaju retoryka nie uzyskała poparcia czy to ze strony elit politycznych, czy też samego społeczeństwa. Nie oznacza to oczywiście, że irlandzki Senat jest wzorem do naśladowania, bo postawienie takie tezy byłoby mocno ryzykowne. Irlandczycy ewidentnie opowiedzieli się za koniecznością reformy drugiej izby swojego parlamentu i od mądrości irlandzkich polityków będzie teraz zależeć, w którym kierunku reforma ta zostanie poprowadzona.

\section{Literatura}

Electoral Act 1997, http://acts.oireachtas.ie (data dostępu: 10.02.2014).

Electoral (Amendment) Act 1998, http://acts.oireachtas.ie (data dostępu: 10.02.2014).

Electoral (Panel Members) Act 1947, http://acts.oireachtas.ie (data dostępu: 10.02.2014).

Kiełmiński Z. [2004], Motywy bikameralizmu we wspótczesnej Europie, „Przegląd Europejski", nr 1.

Konstytucja Irlandii [2006], Kancelaria Sejmu, Wydawnictwo Sejmowe, Warszawa. 
Lane D. [2002], Seanad Éireann [w:] Second Chambers. Bicameralism Today, red. R.C. Tripathi, Rajya Sabha Secretariat, New Delhi.

Programme for Government 2011 (umowa koalicyjna), http://www.merrionstreet.ie/index. php/about/programme-for-government (data dostępu: 5.02.2014).

Seanad Electoral (Panel Members) Act 1954, http://acts.oireachtas.ie (data dostępu: 10.02.2014)

Seanad Electoral (University Members) Act 1937, http://acts.oireachtas.ie (data dostępu: 10.02.2014)

Szymanek J. [1999], Izby drugie parlamentu w procesie ustawodawczym, Studia nad Polityką, Tom VI, Instytut Nauk Politycznych Uniwersytetu Warszawskiego, Warszawa.

Szymanek J. [2004], Kształtowanie składu drugich izb parlamentu (w europejskich państwach unitarnych), Studia nad Polityką, Tom X, Wydział Dziennikarstwa i Nauk Politycznych Uniwersytetu Warszawskiego, Warszawa.

Szymanek J. [2005], Druga izba we wspótczesnym parlamencie. Analiza porównawcza na przykładzie europejskich państw unitarnych, Kancelaria Senatu, Warszawa.

\section{The Irish Senate and an Unsuccessful Attempt to Abolish It}

The article discusses the Senate of the Republic of Ireland and a referendum campaign held regarding a government proposal aimed at abolishing the second chamber of the Irish parliament. This chamber is said to be one of the most bizarre second chambers that exist within European bicameral assemblies. It is the unique method it employs to create its membership that causes it to be regarded as strange. This method has somewhat incapacitated the senate as an institution of power within the Irish political system that additionally reinforces the governmental majority.

The article presents, synthetically, the most important information about the Irish Senate and its powers. It also describes the political and economic circumstances that led to a referendum on the abolition of this chamber of parliament. It shows the arguments of both sides of the dispute over the necessity of such a constitutional reform, the course of the referendum campaign as well as the results of the referendum.

Keywords: bicameralism, Senate, parliament, referendum, Ireland. 